\title{
Family Education and Preservation of the Rurup Tradition
}

\author{
${ }^{1}$ Hetreda Terry* \\ History Education Department \\ Faculty of Social Sciences, \\ Manado State University \\ hetredaterry@unima.ac.id
}

\author{
${ }^{2}$ Sendy Lely Merly \\ Musamus University \\ sendy.melatunan0331@gmail.com
}

\begin{abstract}
This research aims to describe the family role of education to preserve the Rurup Tradition at Tomohon City. The qualitative descriptive method was used in this study and the data was collected by using observation, interview and documentation techniques. To analyze the qualitative data was carried out by interactively and continuously until it is complete, and the data being saturated. The results obtained show that parents through family education as a guide, as a teacher and as an example in preserving the Rurup Tradition. Moreover, family education research had played important parts in preserve Rurup Tradition through handed it down from elders to young generations as the legacy to proven the existence of the Rurup Tradition which is still carring till nowadays. The Rurup Tradition strengthens brotherhood, strengthens unity and support the community member who need guidance and assistance, encourages the emergence of spirit of family members, foster sense of solidarity and togetherness.
\end{abstract}

Keywords: Family, Education, Preservation, Rurup

Tradition

\section{INTRODUCTION}

Inheritance of culture and tradition worthsoccurs when it has been internalized in children since their young age so that it will be properly keep in mind until ages. Through applied the tradition in their daily life indirectly the tradition will be passing down from generation to generation. Education played significant parts to transferred the tradition. From the perspective of education, it would be easy to understand and informed the importance of the noble values of tradition by learning and doing. Family as well playing an important role to disseminate the tradition. Family gives a very decisive influence to build up the children character and personality [1][12].

As social creature, humans couldn't live on their own. In fact, humans need and depend on others, there is mutual relationship among one and each others. In line with development of millennial era, as Indonesian we should proud because Indonesia is one of the country in the world which is rich in diversity of ethnicities, languages, religions and races. Indonesia also known as a country with various kind traditions and cultures where spread widely across Indonesia region [1][7][10]. Diversity was a bless and gift for us that we should acknowledge, respect, appreciate and preserve.

In North Sulawesi there are so many Tradition but not all of them known in worldwide because still lack of research had been conducted, there are several research had been done such as Si Tou Timou Tumou Tou [12]; Traditional Marriage of Sub Ethnic Toutemboan [6]; and Mapalus Tradition [4]. The Local Community of Saroinsong have their own tradition called Rurup. Rurup Tradition itself as a marker of of a local people identity. This tradition makes Saroinsong Community different with another community around them. The way they nurtured and preserved by teaching this tradition from elder people 
to young generation in any occasion they had [2][7]. Local community of Saroinsong has reflected the tradition of Rurup in their daily life. Through this tradition they had shown us that as social human beings, human could not live without other people existence. That's why the tradition of Rurup in Saroinsong Local Community was able to cultivate and encourage an attitude of helping, risen the harmony and careness of others and eventually it would create the harmony in life in social community. The Rurup spirit motivated the local community of Saroinsong to capable to maintain and in the same time preserve the culture as an antidote from modern culture invation which could distracted the community harmony in this globalization era.

Through this research we would analyze and literally study the important role part of family in educated the young generation about to preserve the Tradition of Rurup.

\section{METHODOLOGY}

In this study we had using the descriptive method. Data collection is carried out through several techniques: First, Observation, which is conducting direct observations in order to obtain a clear picture of family education and preservation of the Rurup tradition. Second, through interviews, there is a meeting between researchers and informants to exchange information and ideas through questions and answers, so that meaning can be constructed in the topic of the problem being discussed. Third, documentation is a record of the results of events that have already passed. Documents can be in the form of writings, drawings or monumental works of a person. Namely by studying literature books and other documents related to this research in order to provide detailed, clear, systematic and reliable descriptions. Analysis of the data used in this is using analysis methods from Miles and Huberman [5]. This kind of method done when takes place the data in certain period. For the interviews, researcher had directly analysis the answers of interviewee while held the interview. Whereas to analysis the qualitative data was carry by interactive and let it continuously till complete and that data being saturated. [5]

\section{RESULTS AND DISCUSSION}

The parents' role in order to preserve the Rurup tradition by educate and showing children that tradition is important through their involvement in every Rurup activity which carried out by the community in various moments such as a happy and sad occasions. For example, a happy occasion like wedding party, thanksgiving, baptism and so on. Not just for happy occasion, all the Saroinsong local communities also involved in the Rurup tradition during the sad occasion like funeral ceremony. They did that without coercion or even complaining, because they realize that it is a shared responsibility in fostering the kinship relations among the existing of local community members of saroinsong nowadays.

The culture of Rurup had running great because most of the community members had an awareness and also driven the young generation realize that human couldn't live on his own, they should be live the life surrounding by others. As social human beings believe or not they had a capability to adjust their self in a complex situation, can adapt with a new community environment, and can solve the various kind of problems. But in the other hand, every capability they had couldn't useful if there is no other people help and support they as well. That's why as social human beings maintaining and nurturing good relations with others to bond the brotherhood is urgently needed.

Saroinsong Local Community reside in the village of Tumatantang and Tumatantang I which are included in the administrative area of Tomohon City. The Community itself has unique characteristics that are almost the same as community in Province of North Sulawesi in general. Which is the community has a habit of helping each other between relatives, neighbourhood, and friends and also the habit of always working hand in hand which grows in line with instilling the moral values of noble life. Therefore, in order to maintain sustainability of this tradition, we have to pay attention the the factors which could affect. Inevitable technology progress in current life, the recent situation and condition, the vurnerable of young generation need to be watch carefully in keep the Tradition in the right tracks in the right way. 
The most important value in Tradition of Rurup was the implied of selfless sacrifice for others, mutual assistance among others, prioritizing the common interest. That's the essense and also the core of the Rurup Tradition inself. In apply this tradition there are so many benefits the community could afford such as strengthening the kinship, strengthening the unity, helping and support those in need, encouraging families to stay motivated, fostering solidarity and togetherness. Based on all explanation above, literally the tradition of Rurup in the middle life of Saroinsong local community in Lansot Sub-District could be used as a tools and ways to unifying all the members in community to facing the hard and tough life this globalization era.

The Rurup tradition need to be educate to the next generation since young ages. Parents as a first person had known by the children as a guide and role model for them have play important role for transferring the knowledge of this tradition. Parents are people who are fully responsible in educating and teaching early knowledge to children [8]. Indirectly parents are in control to determine their children future including the succesful of children's education. Anytime and anychance, parents could giving an examples since for the children since their early growth period. By doing that the over and over, this tradition would embedded in the mind of our children and the they will remember and follow the path we had shown them [8][9].

The parents opportunity to disseminate Rurup Tradition to children, in addition to the tradition mentioned above, that the time spent by the children at home was much more if compare with the time they had spent at school or elsewhere. Involving the children in every occasion which could build their understanding to preserving the tradition of Rurup was also important. Directing and encouraging the children to role active in participating at various community activities or occasions such as happy occasion and also sad occasion. Happy occasion in common like wedding ceremony, thanksgiving, baptism and so on. While, the sad occasion for example is funeral ceremony.

Mostly the Saroinsong local community had participating in these kind of occasions and activities, in aims to build togetherness among them. And which must be underlined that all the occasions they had been involve, they did that without coercion or even complaining. They kept in mind that it's already a part of their lives for shared responsibility in order to fostering the kinship relations among the Saroingsong local community members.

Parents and good education could giving a positive impacts for the children's life if wisely applied hand in hand. Of the many functions of education, transformation cultural being one of that fuction. Through education as cultural transformation, it makes all parts in education also have a responsibility to transforming the culture owned by the local community [11] including the culture of Rurup Tradition which carried out by people who lived in Saroinsong Raya. The parts of educational environments, which had a function to transforming the culture consist of informal education, formal education and non-normal education [13]. Not just for Tradition of Rurup itself, every other tradition and culture are need to preserve and inherit elders to young generation as a successors and the future of the nation.

Seeing how urgent and important the role of young generation, even there is a term says that the future of a nation lies in the hands of young people. Indonesian founding father Soekarno also said, give me 10 (ten) young men and I'll shake the world. The young generation will replace the old leader and lead the nations [10][12], it could be better or ever could be worse. Depends how the current generation educate the next generation. Therefore, by fulfill them with knowledge and tradition through providing both formal and informal education, in every level of education starting from basic until higher education. Nowadays, cannot be denied that young generation have create and enhance series of movements for change towards progress. In national development, it not just need physical development but also social and mental development, and the young generation had the spirit for create the social changes towards better direction. Basically, young generation having their own role, there are: a. Agent of change; b. Agent of development and Agent of modernization. [3]

In our community consist of various groups, from chlidren, teenager, youth, and elders. The gaps 
between all groups will disappear if we see from one perspective as a social human beings and in the same time the cultures or traditions act as a tools to unifying all the differences. Thus, there will me no ore contradiction to separate all members in community, because no generation considers themself more important than others. Even if there is still a differences in the way of maturity minds, and the scope of their responsibility to support the family, they all feel equals, have the same responsibility for welfare, safetiness, and sustain the continuity of the present and future generations [12].

\section{CONCLUSION}

The Rurup tradition urgently needed to preserved and fostered continuously by inherit the tradition from elder peoples to the young generation. So there is a big expectation that the next generations will having a prinde in the legacy of their ancestors and eventually it will continue to used as a tool to unifying this community in particular and the nation in general.

\section{ACKNOWLEDGMENT}

Thank You to the members of the Research Team, to my family, to the leader of Social Science Faculty and to the Rector of UNIMA for supporting this Research.

\section{REFERENCES}

[1] Flyinn Elisabeth, 1994. Psikologi Keluarga, Jakarta: Gunung Mulia.

[2] Herimanto dan Winarno, 2017. Ilmu Sosial dan Budaya Dasar, Jakarta Timur : PT Bumi Aksara.

[3] Joesoef, S., 1995. Keluarga di Indonesia dan Permasalahannya, Jakarta : Berita Keluarga Muhammadiyah.

[4] Mansi, L., 2007. Fungsi dan Peran Tradisi "Mapalus" Dalam Masyarakat Minahasa, Sulawesi Utara. Jurnal Al-Qalam No.XX Tahun XIII Edisi Juli-Desember 2007.

[5] Miles Matthew B; Huberman Michael A;1984. Qualitative Data Analysis; ASourccebook of New Methods; Sage Publications, Beverly Hills, London
[6] Najoan, M., Imbar, M., Lonto, A.L., Umbase, R.S and Hetreda Terry., 2018. The Changes of Minahasa's Tradition Marriage Sub Ethnic Toutemboan Society In Raanan Lama Village of South Minahasa. Advances in Social Science, Education and Humanities Research Volume 226: $1^{\text {st }}$ International Conference on Social Science (ICSS 2018). Atlantis Press.

[7] Priyatna, A. 2011. Parenting for Character Building: Panduan Bagi Orang Tua Untuk Membangun Karakter Anak Sejak Dini. Jakarta: PT Alex Media Komputindo Kelompok Gramedia.

[8] Raho, B., 2007 Teori Sosiologi Modern. Prestasi Pustaka Karya, Jakarta.

[9] Sasmita dkk, 1997. Fungsi Keluarga Dalam Meningkatkan Kualitas Sumber Daya Manusia Di Daerah Jogjakarta, Proyek Pengkajian dan Pembinaan Nilai-Nilai Budaya.

[10] Sartini. 2004. Menggali Kearifan Lokal Nusantara Sebuah Kajian Filsafat. Jurnal Filsafat (Jilid. 37, No. 2)

[11] Soekmono R., 1973. Pengantar Sejarah Kebudayaan Jilid III, Yogyakarta: Penerbit Kanisius.

[12] Terry, H., Merly, S.L., and Aksilas Dasfordate. 2019. Character Education Based Local Wisdom Si Tou Timou Tumou Tou Through Informal Education in the City of Manado. Advances in Social Science, Education and Humanities Research Volume 383; $2^{\text {nd }}$ International Conference on Social Science (ICSS 2019) Atlantis Press.

[13] Tirtarahardjo Umar dan La Sulo,S.L., 2008. Pengantar Pendidikan, Jakarta: Rineka Cipta. Widagdho, Djok, dkk, 1994. Ilmu Budaya Dasar, Jakarta : Bumi Aksara. 